\title{
Kant on Moral Freedom and Moral Slavery
}

\author{
David Forman \\ To appear in revised form in Kantian Review 17/1 (2012) \\ http://journals.cambridge.org/action/displayJournal?jid=KRV
}

\begin{abstract}
Kant's account of the freedom gained through virtue builds on the Socratic tradition. On the Socratic view, when morality is our end, nothing can hinder us from attaining satisfaction: we are self-sufficient and free since moral goodness is (as Kant says) "created by us, hence is in our power." But when our end is the fulfillment of sensible desires, our satisfaction requires luck as well as the cooperation of others. For Kant, this means that happiness requires that we get other people to work for our ends; and this requires, in turn, that we gain control over the things other people value so as to have influence over them. If this plan for happiness is not subordinated to morality, then what is most valuable to us will be precisely what others value. This is the root of the "passions" that make us evil and make us slaves whose satisfaction depends on others. But, significantly, this dependence is a moral slavery and hence does not signal a loss, or even diminishment of the kind of freedom required for moral responsibility.
\end{abstract}

\section{Socratic Wisdom and the Freedom of Self-Sufficiency}

Like the Stoics and other Socratics, Kant identifies the ideal of virtue with the sage (der Weise) (MdS 6:383; KrV A569/B597). ${ }^{1}$ This is unsurprising when we consider that Kant equates wisdom (Weisheit) not with intelligence or prudence,

${ }^{1}$ Translations from Kant are taken from The Cambridge Edition of the Works of Immanuel Kant, where available. I have frequently altered these without comment or supplied my own where no translation exists. I use the following abbreviations for frequently cited works of Kant:

Anthropology = Anthropology from a Pragmatic Point of View. In Kant 2007.

GMS = Groundwork for the Metaphysics of Morals. In Kant 1996a.

$K d U=$ Critique of the Power of Judgment. Kant 2000.

$K p V=$ Critique of Practical Reason. In Kant 1996a.

$\mathrm{KrV}=$ Critique of Pure Reason. Kant 1997a.

MdS = The Metaphysics of Morals. In Kant 1998.

Nova dilucidatio $=$ A New Elucidation of the First Principles of Metaphysical Cognition .

In Kant 1992.

Religion = Religion within the Boundaries of Mere Reason. In Kant 1996b.

Remarks on the "Observations" = Bemerkungen in den Beobachtungen über das Gefühl des Schönen und Erhabenen. Kant 1991. 
but rather with the ability to make morality one's end: the consciousness of duty as the incentive of one's action is the "principle of wisdom" that makes a person a "practical philosopher" ( $M d S$ 6:375n; $\left.c f .405_{26-30}, 441_{14-19}\right)$. Hence Kant equates the "doctrine of wisdom" with the proper content moral philosophy itself (5:163) and the requirements of duty with the "rules of wisdom" (Toward Perpetual Peace 8:370). ${ }^{2}$ Kant might seem to depart from this Socratic ideal of wisdom by endorsing the Christian ideal of holiness. Indeed, Kant identifies the proper ethical ideal not with the Stoic sage, but rather with the sage of the Gospel, that is, Christ. 3 But Kant also tells us that the ideals of wisdom and holiness are "identical objectively and in their ground" ( $K p V, 5: 11 \mathrm{n})$. The ideal of holiness merely differs from that of wisdom only insofar as it "deprives the human being of confidence that he can be fully adequate to it, at least in this life" $(K p V 5: 127 n$; cf. Moralphilosophie Collins 27:251f.).

Kant's debt to the Socratic ideal of the sage is especially clear in his remark about wisdom in the Metaphysics of Morals:

Only in its possession is a person free, healthy, rich, a king, etc., and capable of suffering loss neither by chance nor fate, since he is in possession of himself, and the virtuous person cannot lose his virtue.

$\left[M d S, 6: 405_{30-33}\right]$

2 Also see Religion 6:58, Naturrecht Feyerabend 27:132331., Anthropology 7:200, GMS 4:404-5, and KpV 5:104-5, 130-1.

3 See Reflexionen 6708, 6829, and 6882 as well as Wood 2005. 
Kant does not elaborate on this remark, but he clearly means to invoke some familiar ethical ideals associated with the sage of the Socratic tradition. 4 Indeed, all of the characteristics of the sage that Kant mentions here have ancient precedents. 5 In this tradition, what the ordinary person thinks is valuable in wealth, power, etc. is found, in reality, only in the life of the sage. Even bodily health and integrity are not truly valuable, while bodily harm and even death are not truly harmful; only the health of the soul, virtue, is valuable and an authentic benefit to its possessor. Similarly, being a freeman or even a tyrant is not truly

4 Schneewind (1998) quotes this passage in as an example of Kant's positive assessment of Stoicism. But Schneewind does not discuss what this Stoic-sounding passage means in the context of Kant's ethical theory. He is instead concerned to highlight the differences between Kantian and Stoic ethics, some of which I discuss below.

5 Seneca remarks that it is not possible to injure the sage since the only thing that properly belongs to him is his "healthy virtue" (De constantia sapientis V.5-6). Diogenes Laertius attributes to Chrysippus the view that the sage's immunity from harm implies not only freedom, but also kingship: "Not only are the wise free, but they are also kings, since kingship is a form of rule not subject to review, which only the wise could have, as Chrysippus says [...]." (Lives VII.122; in Inwood \& Gerson, 1997: 200). Kingship is associated particularly with the Cynic ideal, for example by Epictetus (Discourses 3.21.19). He attributes the following claim to Diogenes the Cynic: "Who, when he sees me, does not think that he is seeing his own king and master" (Discourses 3.22.49f.; cf. §34). Diogenes Laertius remarks further: "Hermippus, in his Sale of Diogenes, says that he was taken prisoner and put up to be sold, and, asked what he could do, answered, 'Govern men.' And so he bade the crier 'give notice that if anyone wants to purchase a master, there is one here for him" (Lives VI.74; see Kant's Anthropology 6:292n) Epictetus remarks regarding wealth: "I am richer than you. I am not anxious about what Caesar will think of me. I flatter no one on that account. This I have instead of your silver and gold" (Discourses 3.9.18). And when Kant says that "the virtuous cannot lose his virtue" he obviously does not mean that a virtuous person cannot become vicious, but rather than no external circumstances can rob him of his virtue since it is wholly within his own control. That Kant associates all of this with the Stoic ideal in particular is clear from his ethics lectures: "the pattern or archetypal idea of Zeno is the sage, who feels happiness in himself, who possesses everything; he has in himself the source of cheerfulness and uprightness; he is the king insofar as he rules himself" (Moralphilosophie Kaehler, p. 18; Moralphilosophie Collins, 27:250 2-7). 
valuable, and being a slave (in the legal sense) is not truly harmful. Indeed, what the ordinary person thinks is valuable about the tyrant's life is in fact illusory: his unruly desires make him dependent on other people and hence a kind slave-in a spiritual rather than a legal sense. The sage, on the other hand, cannot be controlled or manipulated by others since he aims only at virtue: he does not value what others can take away from him.

This tradition suggests that the passage from the Metaphysics of Morals should be taken to be endorsing the following contrast. The person who finds satisfaction only in the fulfillment of his sensible desires is not in control of his own fate: he can try his best to ensure that his sensible desires are fulfilled, but their fulfillment depends, ultimately, on the course of nature or the whim of other human beings. But since virtue, by contrast, requires no fulfillment of such sensible desires, nothing can hinder the virtuous sage from satisfaction in the pursuit of his end. We can call this freedom, the Stoics' eleutheria, the "moral freedom" of the sage. ${ }^{6}$

The Kantian account of such moral freedom is closely connected to Kant's more well-known (and well-developed) account of moral goodness: the only thing that is unconditionally good is a "good will," which is "not good because of what it effects or accomplishes, because of its fitness to attain some proposed end, but only because of its volition; that is, it is good in itself" (GMS, 4:39413-15). This can be compared, for example, to Epictetus' denial that any "externals" (ta ektos) are good and his definition of the good as instead "a certain disposition of our choice" (prohairesis poia).7 For Kant, this means that virtue is an end "sufficient for itself independently of nature," such that the human being must "separate from this

\footnotetext{
${ }^{6}$ Kant himself does not restrict the term "moral freedom" to this type of freedom.

7 Discourses 1.29.1-2.
} 
[end] all those ends whose possibility depends on conditions which can be expected only from nature" $\left(K d U, 5: 431_{3-17} ; c f .4347 \mathrm{f}.\right) .{ }^{8}$ That is, the moral end is concerned merely with good willing itself rather than accomplishing some effect in the world-an effect that can always be thwarted by forces outside our control. In short, unlike natural goodness, moral goodness "is created by us, hence is in our power" (Reflexion 7202 [1780-89], 19:281 22-26).

For the Stoics, it is precisely this feature of good willing-that it is in our power-that makes the sage free. Epictetus, for example, emphasizes the importance of distinguishing what is in our power (or "up to us": eph' hêmin) from what is not:

Some things are up to us and others are not. Up to us are opinion, impulse, desire, aversion, and, in a word, whatever is our own action. Not up to us are body, property, reputation, office, and, in a word, whatever is not our own action. The things that are up to us are by nature free [eleuthera], unhindered and unimpeded; but those that are not up to us are weak, servile [doula], subject to hindrance. 9

That is, a person is free and "his own master" when he treats all those external things not in his power as indifferent, as not "his own" and cares only about what is truly his own, that is, only about his own willing or choice: for "who has any authority over these, who can take them away? Nobody can, any more than he could hinder a god."10 The sage cares only about what is his own, about his virtue,

\footnotetext{
8 For the connection between "wisdom" and having a "good will" in Kant, see Engstrom 1997.

${ }_{9}$ Handbook 1.

${ }^{10}$ Discourses 4.1.62-82.
} 
and thereby lacks the passions connected with "externals" that put the fool at odds with other people and make him vicious.

\section{Moral Freedom and Happiness}

For the Stoics, this ideal of freedom is also connected with that of happiness or well-being (eudaimonia). Everyone seeks happiness, and happiness requires that we lack nothing that we want. ${ }^{11}$ The happiness that everyone seeks is therefore attainable only for those who care only about what is in their own power, only about their own good willing; unhappiness comes not from external things, but from our caring about them. ${ }^{12}$

Kant makes an important break from this Stoic view when he denies that the satisfaction attained through virtue could itself count as happiness. ${ }^{13}$ For Kant, happiness is a physical well-being that requires the satisfaction of sensible desires. The satisfaction accompanying virtue is, for Kant, thus merely "an analogue of happiness" ( $K p V, 5: 117)$; such satisfaction can offer us, at best, some consolation if we have sacrificed happiness for the sake of virtue. For Kant, even the virtuous person also seeks physical well-being as something good. Indeed,

${ }^{11}$ E.g., Epictetus, Discourses 4.1.46, 3.24.17.

${ }_{12}$ Epictetus: "It is not things themselves that disturb people, but their judgments about those things" so that "You will be hurt when you think you are hurt" (Handbook, 5, 30). Unlike the layman, the philosopher "expects all harm and benefit from himself" (Handbook 48). Thus: "if anyone is unhappy, remember that he himself is responsible, for god made all mankind to be happy, to enjoy peace of mind. He has furnished them with the resources to achieve this, having given each man some things for his own, and some not his own" (Discourses 3.24.1).

${ }^{13}$ Kant complains in this regard that the Stoics "made their sage, like a divinity in his consciousness of the excellence of his person, quite independent of nature (with respect to his own satisfaction) [...]; and thus they really left out the second element of the highest good, namely one's own happiness [...]-though in this they could have been sufficiently refuted by the voice of their own nature ( $K p V, 5: 127)$. 
one cannot have attained the highest human good unless one achieves both virtue and physical well-being. Kant's view is, of course, that the value of physical wellbeing must be subordinated to the value of a morally good disposition. But physical well-being must not be considered a mere "preferred indifferent," as the Stoics supposed. ${ }^{14}$

One consequence of Kant's rejection of this aspect of Stoic doctrine is that he cannot claim that the sage literally cannot be harmed. Hence when Kant says in the remark from the Metaphysics of Morals that the sage "is capable of suffering loss neither by chance nor by fate," he must mean that the sage cannot lose what is most important to him, namely his virtue, though he may very well lose his happiness, which he also counts as something good (but $c f . K p V 5: 6 \mathrm{O}_{26-29}$ ).

Rather than claiming with the Stoics that we can satisfy our aspiration for happiness by turning away from sensible desire and toward virtue, Kant takes the view that our ability to satisfy our aspiration for happiness is extremely limited. To that extent, Kant treats happiness in a way analogous to how the Stoics treat the external things. For Kant, happiness is an ideal of the imagination rather than reason since knowing what would make one happy would require omniscience (GMS 4:418-9).15 Indeed, Kant even suggests that the more we try to devise a plan for our happiness, the unhappier we become (e.g., GMS 4:395f.).16

\footnotetext{
14 This point is rightly emphasized by Jerome Schneewind (1998: 296-7) and Jeanine Grenberg (2005: 19-22).

15 And without omniscience, even omnipotence would not be sufficient to secure our happiness ( $\left.K d U, 5: 430_{12-16}\right)$. But, by the same token, even omniscience concerning the course of the world could not ensure the satisfaction of our desires unless we either (a) are able to restrict our desires to what we know we can satisfy (that is, expunge all our "wishes") or (b) have the omnipotence to ensure that the course of the world will result in the fulfillment of all our desires. Kant's repeated emphasis on our lack of omniscience rather than omnipotence can perhaps be traced to his rejection of the Wolffian account of wisdom. On that account, wisdom consists in the
} 
Kant notes this difference between the ends of virtue and of fulfilling sensible desire quite early in his career:

The longing for mere well-being must therefore, by the law of mutability, already make for unhappiness-since all physical things relate to the whole and cannot always affect us favorably. The morally good, in which we are the ground, is thus immutable and fruitful in physical goodness, so that everything which comes about through me must come from moral goodness"

[Praktische Philosphie Herder [1762-4], 27:468-13]

Kant claims something he here later comes to reject: that the satisfaction arising from moral goodness is a secure source of physical goodness in this life, namely happiness. ${ }^{17}$ But the pessimism about our ability to make plans for happiness persists in Kant's mature view and suggests a continued affinity with the Cynic's notion that the simplicity associated with a virtuous life offers the best chance for happiness. ${ }^{18}$

knowledge of "the connection of things" in the world that ensures that a person's "particular ends lead to his principle end” (see German Metaphysics §§912-914 and German Ethics §§314-316).

${ }^{16}$ Kant attributes this insight to Diogenes the Cynic and to Rousseau, "that subtle Diogenes" (e.g., Moralphilosophie Collins 27:248). And in lectures dated shortly before the Groundwork, Kant apparently attributes a similar view to Cicero (Naturrecht Feyerabend, 27:1330 24-27.).

17 In the 1760s, Kant endorses the ideal of "wise innocence" (Announcement of the Programme of his Lectures for the Winter Semester 1765-1766, 2:312) and "wise simplicity" (Dreams of a Spirit-Seer 2:369), without, however, associating this ideal with Rousseau. And in his notes, Kant praises the Cynic ideal as "correct in theory, but very difficult in praxis, although the norma" (Reflexion 6607 [1769?], 19:1073-4).

${ }^{18}$ In The Conflict of the Faculties Kant remarks: “Stoicism as a principle of regimenting one's life (sustine et abstine) thus belongs to practical philosophy not merely as a doctrine of virtue, but 
Unlike the ancients, who saw happiness as something within our control to attain, Kant takes the Christian view that no human exertions can give us complete control over our own happiness; that control belongs ultimately to God, and our hopes for happiness therefore rest not in this life, but rather in the happiness rewarded for virtue in the next. The best we can do is aim to be worthy of happiness and hope happiness will follow (KpV 5:1292-7). Kant strikes a particularly gloomy note in his lectures: "Here on earth no human being can be happy. Maybe somewhere else" (Moral Mrongovius II, 29:60422f.). ${ }^{19}$ Kant is thus led to the very un-Stoic position that we cannot attribute happiness to the sage. Accordingly, "happy" is conspicuously absent from the list of attributes of the Kantian sage given in the Metaphysics of the Morals.

But despite this important difference with respect to the ideal of happiness, Kant agrees with the Stoics on the central point we are concerned with here: that only in virtue does rational choice operate solely within its own domain, that only in virtue is reason self-sufficient such that nothing can hinder it from attaining satisfaction. Kant captures the central point of the Socratic account of moral freedom when distinguishing, along these lines, the moral demands of virtue from the prudential demands of politics:

The god of morality does not submit to Jupiter (the god of power), for the latter is still subject to fate. That is, reason is not enlightened enough to survey the series of predetermining causes that would allow

also as medical science" (7:100; $c f . M d S$ 6:483f.). But this regimen should not degenerate into a monkish denial of one's natural needs (On the Philosophers Medicine of the Body 15:948 5-11, 942 $^{\text {- }}$ $\left.{ }_{14}\right)$.

19 Kant thereby takes the view of Aquinas against the heathen view of the Stoics: "It is impossible for the final happiness of a human being to be in this life" (Summa Contra Gentiles III cap. 48; also see Summa Theologiae Ia-IIae q. 5 art. 3 s.c.). 
one to predict with certainty the happy or unhappy consequences that follow from men's activities in accord with the mechanism of nature (though one can hope that they come out as one wishes). But with respect to everything we have to do in order to remain on the path of duty (according to rules of wisdom), and thus with respect to our final end, reason does enlighten us with sufficient clarity.

[Toward Perpetual Peace 8:370 $27-35]^{20}$

Kant is even willing to call the satisfaction arising from virtue "moral happiness" as long as we strictly distinguish it from the "physical happiness" attained by satisfying desires (Religion 6:67, 6:75n; $c f . M d S$ 6:387). Reason is not capable of achieving the satisfaction of happiness, but instead is "capable only of its own kind of satisfaction [Zufriedenheit], the satisfaction of fulfilling an end which in turn only reason determines" (GMS 4:396)-namely the end of willing according to the moral law. And this moral happiness, like the Stoics' eudaimonia, is a happiness that does not depend on nature or other people. The human being cannot achieve the complete self-sufficiency imagined by the Stoics, but following moral maxims still results in an "intellectual contentment," namely a "contentment with oneself, which in its strict meaning, always designates only a negative contentment with one's existence, in which one is conscious of needing nothing" ( $K p V$ 5:117-8; second emphasis added). Virtue produces a consciousness of independence from inclinations "and so too from the

${ }^{20} \mathrm{Cf}$. GMS, 4:416n. Kant remarks in this regard in a Reflexion concerning the contrast between the principle of eudaimonism and the principle that the supreme good is the worthiness to be happy: "The former places the supreme condition of the highest good in that which is very dependent upon chance; the latter in that which is in our power at all times. The former requires much experience and cleverness in its application; the latter nothing more than to make one's will universal and to see whether it agrees with itself" (Reflexion 7242 [1780-89], 19:2932-15). 
dissatisfaction that always accompanies them," an independence that is even "analogous to the self-sufficiency [Selbstgenugsamkeit] that can be ascribed only to the Supreme Being" (5:118). ${ }^{21}$ It is this feature of the moral end that justifies Kant's claim in the passage from the Metaphysics of Morals that only the virtuous person is, although not happy, "capable of suffering loss neither by chance nor fate, since he is in possession of himself, and the virtuous person cannot lose his virtue," which in turn gives content to the description of the sage as "rich," "a king," and especially as "free."

\section{Evil Self-Sufficiency?}

Perhaps it is necessary to forestall a certain objection here on Kant's (and, indirectly, the Stoics') behalf. An objector might admit that the end of virtuous willing is always in my power to attain, whereas as an end that involves fulfilling a certain sensible desire, e.g., my end of attaining wealth, can never be completely within my power to attain. The objection is that using that distinction to arrive at a substantive result regarding self-sufficiency seems like mere verbal trickery. I can say I am in control of attaining the end of being virtuous only because that end is merely to will in a certain manner as opposed to actually willing to achieve any particular result. And no matter what my end is, I can always be said to will that end in a certain manner, even if it is, for example, selfishly. So why can't I say, similarly, that willing selfishly is my end and that in this case too it is completely within my power to attain this end? And why can't I therefore say that my selfishness in pursuing wealth makes me free? The thought motivating the objection is this: it seems to be a virtual tautology to point out that I am in control

${ }^{21}$ This recalls not only Leibniz's claim that only God can fully attain a freedom from bondage, but also classical Stoic views. 
of the manner of my willing, and it therefore seems meaningless to say that I achieve some special kind of freedom through virtue, which is only one possible manner of willing.

Kant's defense against this objection will rest, of course, on the fact that the end of virtue is unique in this regard. While it is certainly true that virtuous willing always involves some specific ends, e.g., increasing my neighbor's welfare, willing virtuously is not merely one manner among others of pursuing ends that aim at satisfying sensible desire. It is instead a manner of willing in which I pursue particular ends only because it is virtuous to do so and not at all because those ends serve to satisfy sensible desire. Thus, if increasing my neighbor's welfare is my end only because that end would satisfy some desire of mine, then it is impossible to will that end virtuously. Conversely, if my end is amassing wealth, then I may pursue this end selfishly, but I do not pursue this end simply because doing so is selfish: I am interested in the wealth and what it buys, not in selfishness. And in this sense, selfish willing cannot in any sense be called my end.

One might object further that I could, in fact, pursue wealth simply because I want to be selfish so that I achieve my end so long as I have willed selfishly and thus regardless of whether I actually attain that wealth. In that case, I would not be acting on any incentive rooted in sensibility, but rather on a disinterestedly or purely evil incentive, as we could say. But this rejoinder concedes the main point at issue: that we can coherently distinguish a self-sufficient agent from the more ordinary agent who can achieve his end only with the cooperation of nature and other people. Nevertheless, by allowing the possibility of an evil self-sufficiency, this rejoinder does threaten to undermine the claim that virtue is unique bringing moral freedom. But this is less of a threat than it appears since Kant does not claim that self-sufficiency is what makes the virtuous disposition choiceworthy or 
good. Moreover, Kant has a direct response at his disposal: the kind of evil selfsufficiency imagined by this rejoinder is not any human kind of evil but is rather a diabolical (teuflisch) evil. It might be logically possible to attain self-sufficiency through evil, but that does not mean that there is any comprehensible motive for anyone to act out of a disinterested attraction to evil.

Kant does describe a kind of human approximation to diabolical evil: evil arising from a firm and self-consciously chosen principle, that is, from what Kant calls "character." Such a character suggests a kind of "strength of soul" analogous to that of virtue since the person of character is concerned with acting on principle rather than agreeable results and thus with his own willing rather than simply the expected effects of his willing (Anthropology 7:292f.). But Kant claims that even such a character would remain bound, even if indirectly, to sensible inclinations and thus to the hope for their satisfaction: to be truly principled in one's action would be to be interested solely in the action itself and not at all in the result or "object of the action" (see GMS 4:413n); and for Kant we take such an immediate interest in the action itself "only when the universal validity of the maxim of the action is a sufficient determining ground of the will" (4:46on). This means that for Kant an evil character is not even a character in the strict and proper sense: "character requires maxims that proceed from reason and morally practical principles" (Anthropology 7:293).22 The human being never chooses evil wholly on principle: he "never sanctions the evil in himself, and so there is actually no malice arising from principles, but only from the forsaking of them" (ibid.). Strictly speaking, then, even "great crimes" arise not from strength of soul but rather from "the force of inclinations that weaken reason" ( $M d S$ 6:3848-29).

\footnotetext{
${ }^{22}$ Frierson (2006) offers a somewhat different (but, I think, ultimately compatible) account of the relationship between having a character and morally good character (pp. 632-4). I discuss the (relatively) disinterested nature of an evil "character" in Forman (forthcoming).
} 
Although Kant criticizes the Stoics for lacking an account of positive evil, he nevertheless follows the Socratic view that the human being aims at evil sub specie boni and thus does not "incorporate evil qua evil into his maxim to serve as an incentive" (Religion 6:37; cf. KpV 5:5912-14).

So the proper response to the objection that an evil will could also be selfsufficient, and in that sense free, is (1) that such a will would have to be not merely evil, but rather disinterestedly and hence diabolically evil and (2) that diabolical evil is not possible, at least for human beings. Kant seems to go even further than this second point when he claims that it is "absolutely impossible" for a free being to renounce the authority of the moral law, where the apparent implication of this claim is that a diabolical evil is not just foreign to humanity but rather a self-contradictory concept (Religion 6:35). But Kant's response to the objection does not rely on that (obscure) conceptual point since all it needs is the weaker claim that human evil is never disinterested or wholly principled. To be sure, it would be difficult to establish even that weaker claim with certainty (let alone necessity) absent the kind of conceptual point just noted. But we can still attain the certainty appropriate to the case. In the first place, recall that Kant thinks that the possibility of principled good action cannot just be assumed-but must instead be grounded in a conception of a supersensible moral worldprecisely because such action does not base its incentives on any inclinations or desires. But we lack any corresponding grounds for supposing the possibility of principled evil action. Second, we can show that the idea of a diabolical evil is dispensable by accounting for the various kinds of moral evil that we encounter around us and in ourselves in terms of people's indulgence of their sensible desires. Kant's account of the passions can be read as offering us a view of how a perverted subjective conception of the good can bring more than a mere lack of virtue, but rather this kind of positive evil. Once that promissory note is paid, we 
will be able to respond more adequately to the present line of criticism: immoral willing, even (relatively) principled immoral willing, always aims at an end whose attainment is always very uncertain, depending as it does on chance and the whim of other people; moral willing is unique in aiming at something completely within our control, and hence unique in bringing moral freedom.

\section{Moral Freedom and Transcendental-Practical Freedom}

It is important that this "moral freedom" of virtue not be confused with the kind of freedom required for moral accountability. There is no need to see Kant, any more than the Stoics, as claiming that I somehow relinquish responsibility for my actions to outside forces when I pursue sensible desires. Kant can be taken to mean instead that I cannot attain the end that I set for myself through my own exertions alone if that end involves the fulfillment of sensible desires. Since the end of virtuous willing is the only end that can be attained without the cooperation of external forces, it is also the only end that is completely within my control to attain-which of course is not to say that virtue is therefore easy to attain. It is a separate question whether I am in control of willing the end that I do. For the Stoics and Leibniz, we can be considered in control of willing the end that we do as long as that willing follows from our own nature or character. For Kant, this is a necessary, but not a sufficient condition for moral responsibility. Kant insists that we must, in addition, be responsible for that character itself. Our freedom therefore must be not merely the practical freedom of acting on reasons rather than sensible impulses, but also the transcendental freedom of complete independence of all external causes. ${ }^{23}$ On either view, merely having this control

\footnotetext{
23 Moral responsibility clearly requires at least practical freedom, but Kant's considered view is that practical freedom presupposes transcendental freedom (e.g., $K r V$ A533f./B561f.). More to the point: Kant is explicit that moral responsibility presupposes transcendental freedom. Kant
} 
over willing an end cannot be equated with willing an end that makes one free in the sense of being self-sufficient. 24

This allows us to see that an account of moral freedom, even a Kantian account of moral freedom, can be developed without any commitments to Kant's distinctive metaphysics of freedom. In fact, we can find in Kant's early ethical notes and lectures thoughts on moral freedom that are continuous with his mature views on the topic. ${ }^{25}$ It would be rash to assume that these early thoughts

thus complains about a Leibnizian, compatibilistic conception of freedom: "they therefore leave no transcendental freedom [...]; without this freedom (in the latter and proper sense), which alone is practical a priori, no moral law is possible and no imputation in accordance with it" ( $K p V$ 5:96-7; cf. KrV A555/B583). Kant sums up his difference from Leibniz in an early note where he says that we impute actions arising even from the "innate character" of a person not only because "each has still acted in accordance with his preference and inclination and thus not against his own inclination" (the Leibnizian point), but also because "everyone has a higher power of choice under which even this character stands" (Reflexion 4551 [1772-1773], 17:59of).

24 The fundamental difference between these two topics (eleutheria and responsibility) in Stoic thought is emphasized persuasively and in great detail by Suzanne Bobzien. She points out, for example, that the early Stoics even relegated these two topics to two different types of treatise: questions related to concerns about responsibility were discussed in physical treatises, whereas questions about freedom (that is, about moral freedom or eleutheria) were discussed in ethical treatises (Bobzien 1998: 331-332).

25 His later views are of course suitably altered to reflect the changes in his account of the principle of morality. The present paper focuses on Kant's mature writings. The richest source for Kant's developing account of this Socratic moral freedom is found in the Remarks on the "Observations." Kant is occupied with the question of freedom throughout these notes, but almost always in Rousseau's sense of "moral" or (less often) "civil freedom" and rarely in the sense of what Kant would later call "transcendental freedom." For example, after a discussion of a kind of independence from other people, Kant notes: “That freedom in the proper sense (moral not metaphysical) is the highest principium of all virtue and all happiness" (Remarks in the "Observations" 20:31 $1_{10-12}=$ \#2514ff.). For a discussion of the account of freedom in the Remarks, see e.g., Guyer 2005, Guyer 2007, Velkley 1989: ch. 3, Zammito 2002: 113-120. Both Velkley and Zammito rightly emphasize the influence of Rousseau. We will see below that this influence highlights the Socratic character of Kant's account of moral freedom. 
concerning moral freedom offer an alternative to the mature account of (what we can call) transcendental-practical freedom. ${ }^{26}$ Indeed, Kant continues to endorse a roughly Stoic account of moral freedom in his mature work even though he labels Leibniz's Stoic-influenced account of free will as a "wretched subterfuge." The mature Kant does, of course, hold that we can speak of virtue and vice only where the agent can be considered practically free and even transcendentally free. But this account of transcendental-practical freedom represents Kant's account of the conditions of moral responsibility. The account of moral freedom is independent of this set of problems since it is not concerned with our ability to adopt ends or, more generally, with our responsibility for our practical character and its effects; it is concerned rather with the different moral and pragmatic implications of aiming at different ends and, in particular, with our ability to attain our adopted ends. In fact, Kant's account of moral freedom had better be independent of his account of transcendental freedom: if it is not, then an immediate problem would arise about how we could be responsible for our immoral actions. ${ }^{27}$

${ }^{26}$ Guyer (2005: 117) correctly notes the connection for Kant between the dependence on others and the dependence on external things engendered by overvaluing the inclinations. He discusses this equation with particular reference to the early Remarks (127-132). But, in my view, it is a mistake to equate this independence (from others and external things), as Guyer does, with autonomy, and thus with the account of the freedom necessary for moral accountability. It would also be a mistake to equate the freedom achieved through virtue with "positive freedom." For Kant there is no such thing as a "positive freedom" that someone with "negative freedom" could lack. There is instead a negative and positive concept of transcendental-practical freedom (GMS $4: 446)$.

${ }^{27}$ Guyer sees Kant's mature account of autonomy as spoiling some of his earlier thoughts on (what I have been calling) moral freedom in precisely this way. The account of autonomy introduced in the Groundwork has, on Guyer's reading, the following consequence: "a free will cannot but choose in accordance with the fundamental principle of pure practical reason, and thus, freedom of the will is not only a necessary but also a sufficient condition for the achievement 
Both kinds of freedom concern a kind of control over our actions. But transcendental-practical freedom concerns the control we have over our own ultimate choices or practical character, whereas moral freedom concerns our control with respect to the attainment of our end and, by extension, the attitude of mind in choosing an end that makes one's satisfaction independent of nature and other people. The two kinds of freedom are related in the following way: I am in control of attaining my end and thus have moral freedom only when my end falls solely within the scope of my power of transcendental-practical freedom. That is the Kantian way of putting the Stoics' point that moral freedom requires we care only about what is "up to us."

\section{Inner Freedom as the Moral Freedom Distinguishing Moral from Legal Conduct}

Kant's discussion of the "inner freedom" of virtue in the Metaphysics of Morals might seem to undermine this tidy distinction between the transcendentalpractical freedom possessed by all human beings and the moral freedom attained

of autonomy, understood as practical freedom, or as freedom from domination by one's sensory impulses and, therefore, as freedom from domination by others as well." And this implies that we are not responsible for action performed under such domination (Guyer 2005: 123). Carl Reinhold (1975) offers an early criticism of Kant along these lines in the Eighth Letter of the second volume of his Letters on the Kantian Philosophy of 1792. As Guyer notes in this connection, Henry Sidgwick's (1888) criticism been influential in the English-speaking world. (See Korsgaard 1996 and Hudson 1994: 149-151.) But if we see the mature accounts of autonomy and transcendental freedom as answering a different set of problems (namely those associated with responsibility), there is no need to see those accounts as spoiling, or even in conflict with, the earlier account of moral freedom. Nevertheless, showing the availability of a principled distinction between moral freedom and transcendental-practical freedom can only serve as a partial response to this line of criticism. A full response would require something not offered here: an interpretation of Kant's equation of freedom with moral self-legislation (autonomy) that leaves room for immoral willing. 
with virtue. Kant defines ethical duties as "duties of inner freedom" (6:406) and explains: only a free aptitude (freie Fertigkeit, habitus libertatis) to act in accordance with the law counts as virtue since if the aptitude is a habit (Angewohnheit, assuetudo) "it is not one that proceeds from freedom and therefore not a moral aptitude" (6:407). Indeed, "if the practice of virtue were to become a habit [Gewohnheit], the subject would suffer loss to that freedom in adopting his maxims which distinguishes an action done from duty" (6:409). When Kant speaks here of the loss of a person's “freedom in adopting his maxims" it seems most natural to take him to be referring to a loss of transcendental-practical freedom, that is, control over our own choices or practical character. But although this is clearly the most natural reading of the passage considered in isolation, it is also highly problematic: if only an action done from duty is the result of transcendental-practical freedom, then only an action done from duty will be something for which we are responsible; and the implication of this, of course, is that we would lack such freedom when we adopt an evil maxim and hence that we would not be responsible for moral evil. This is not only an unwelcome consequence; it also contradicts Kant's guiding principle that the human being's power of choice can be determined only by an incentive that is freely incorporated into his maxim (e.g., Religion 6:24; cf. MdS 6:320n)..$^{28}$

\footnotetext{
${ }^{28}$ Hence Engstrom concludes (correctly, in my view) that Kant is not talking about practical freedom (the freedom required for responsibility) when he talks about a freedom that is found only in action done from duty and that is lacking in actions from habit (Engstrom 2002: 297f.). Engstrom draws the following distinction: whereas practical freedom is the independence of the power of choice from determination by sensible impulses, the inner freedom attained through virtue is an independence even from the influence by sensible impulses (even though the virtuous human being remains affected by sensible impulses) (300). One difficulty with this interpretation is that the key passage to which Engstrom refers us in making the case that the lack of "influence" is a condition for inner freedom is not clearly referring to anything other than practical freedom itself: Kant says there that inner freedom is the capacity to be independent of the influence of
} 
Moreover, even the passage under consideration clearly implies that actions that do not arise from a free aptitude would still be "free actions" (6:40711-14).

To understand Kant's intent in speaking of "inner freedom" here, it is essential to note the context: a discussion of the distinction between the doctrine of right and the doctrine of virtue and hence the distinction between merely legally good and authentically morally good willing (in which morality is the sufficient incentive determining the will to action). This context-along with Kant's repeated allusions in the surrounding text to the Stoic doctrines of freedom, self-mastery and apathy-suggest that the "inner freedom" described here is nothing other than what we have called "moral freedom." The concept of moral freedom serves to distinguish ethical duties from duties of right since however much one's conduct respects the outer freedom of others (and is thus dutiful by the standards of right), the principle of one's conduct will not be consistent with an inner, moral freedom unless one does one's duty from duty. Only then does one adopt a maxim without a view to results that make one's satisfaction dependent on external circumstances and especially on other people; for only then does one have an aptitude that "proceeds from freedom" in the sense that the standard for correctness of the maxim lies wholly within

inclinations (p. 298, $K p V$ 5:161). Engstrom points out in a different context that Kant sometimes uses the term "inner freedom" to mean practical or transcendental freedom (e.g., MdS 6:418 17-20), and this seems like it might be one of those places: as Engstrom himself also points out, practical freedom itself can be understood as the "capacity to be independent from such influence" (301). Engstrom is surely correct, then, on the following two essential points: (1) virtue can be characterized in terms of an inner freedom that is possessed by someone who aims to act from duty and that is lacking in someone who aims to act merely in conformity with duty; and (2) virtuous willing is independent from even the influence of sensible impulses and inclination. Overall, I am inclined to say that Engstrom's definition of inner freedom is correct as far as it goes, but incomplete. It is here that the Socratic view of freedom, to which Kant alludes repeatedly in this context, can help us understand why the independence of the influence of sensible impulses should count as a kind of freedom. 
(transcendental-practical) freedom itself, namely in the law of freedom (the moral law).

For Kant, this ideal of the freedom that distinguishes morally good from merely legally good willing is personified in its purest form by Jesus. On Kant's telling, the Jewish theocracy is a kind of metaphor for mere legality: it was a government instituted for the purpose of the veneration of the moral law, but its subjects wished "to be ruled through rewards and punishments in this life," such that the laws were "in part indeed ethical but only inasmuch as they gave rise to external coercion" (Religion 6:79). This people was "ripe for a revolution" when Jesus begin teaching - not only because they suffered the "evils of a hierarchical constitution," but also because their "slavish mind" (Sklavensinn) became unsettled and more reflective due to the influence of "the Greek philosophers' moral doctrines on freedom" (6:79f.; $c f$. 127f.).29 But Jesus displayed a wisdom

29 It hardly needs mentioning that this is a pernicious distortion of the nature of the disposition toward the law required by Judaism-one that even plays on the stereotype of Jews as ultimately concerned only with worldly goods (money) and consequently as untrustworthy ( $c f$. Anthropology 7:205n). And Kant should know better. Earlier in his career, he praised Mendelssohn's Jerusalem as showing the centrality of "freedom of conscience" to Judaism and any authentic religion (10:347). (See Shell 2007: 108 et passim.) And Kant himself suggests that the idea of a moral faith-"the kind of faith that founds not a religion of sycophancy (der Gunstbewerbung), but rather a religion of good life conduct"-is already exemplified by Job in the Hebrew Bible (Miscarriage of all Philosophical Trials at Theodicy 8:267; cf. Shaftesbury 1999: 19). The most one can say on Kant's behalf is that he qualifies this account of the contribution of Jesus by saying that it is merely a "story" that represents in a "popular" way what is actually an internal relation within each human being and not dependent on any historical events (Religion 6:78, 83). And Kant does at least credit Judaism within this story with allowing the good principle to retain a hold in the world despite the universal human propensity to evil (6:79). Moreover, Kant's subsequent account of religion does not leave the ordinary Christian dominations looking any less "slavish" than the caricature of Judaism he presents here. To the contrary: "Our burden will not be lightened in the least by throwing off the yoke of external observances [represented by the Hebrew Bible] if another is imposed in its place, namely the yoke 
"even purer than that of previous philosophers"-a wisdom he proved by refusing the devil's bargain: to wield power over the whole earth in exchange for an inner subservience to the devil (6:8of.). Instead, he endured the most extreme suffering and death without relinquishing his inner commitment to the good principle. This death could be considered a defeat solely in physical terms since that very physical defeat exhibits a holy will that cannot be defeated even by the greatest imaginable rewards or punishments (6:81).

However, since the realm in which principles (be they good or evil) have power is not a realm of nature but of freedom, i.e., a realm in which one can control things only to the extent that one rules over minds and therefore where nobody is a slave (bondsman) except he who wills-and only so long as he wills-to be one: so this very death (the highest rung of the suffering of a human being) was the exhibition of the good principle, that is, of humanity in its moral perfection, as an example calling everyone to discipleship. [... I]t most strikingly displays the contrast between the freedom of the children of heaven and the bondage of a mere son of earth. [... B]y exemplifying this principle (in the moral idea) he opened the gates of freedom to all who, like him, choose to deaden themselves to everything that holds them, to the detriment of morality, fettered to earthly life [...]; while he abandons to their fate all those who prefer moral servitude. $[6: 82]^{30}$

of a profession of faith in sacred history, which, for the conscientious, is an even more onerous burden" (6:166n; emphasis added). Kant remarks in a note dated to 1800: "Der lohnsüchtige Glaube: Bibel" (Reflexion 7321, 19:316 ${ }_{17}$ ).

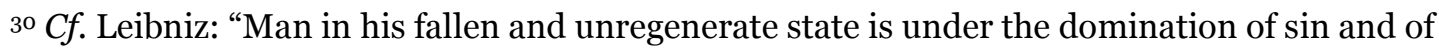
Satan because it pleases him to be so; he is a voluntary slave through his evil lust. Hence a free 
If we remove its "mystical cover," this story has a purely rational meaning not dependent on any historical event (nor on the metaphor of two persons, good and evil, outside the human being):

Its meaning is that there is absolutely no salvation [Heil] for human beings except in the innermost adoption of genuine moral principles; that this adoption thwarts not sensibility, which is so often blamed, but rather a certain self-incurred perversity [...].

That is, good willing is possible only insofar as we act solely for the sake of morality without a concern for punishments and rewards. In that case, we remain subject to physical defeat, but not moral defeat. The slave is the one who is concerned only with rewards and punishments. Thus, Kant remarks that Christianity, properly understood, seeks to instill not a servile obedience to moral obligation, but rather to instill a moral obedience to the law that arises from "the liberal way of thinking, as distant from a slavish mind as it is from unruliness" (The End of All Things, 8:338).

In the passages from the Metaphysics of Morals discussing "inner freedom," Kant is particularly concerned to counter the view that virtue could be defined as "a habit of morally good actions steadily acquired through practice" (6: 383). That definition is deficient since it fails to account for the specific difference between right and ethics. According to the doctrine of right, "one can begin with the end and seek out the maxim of actions in conformity with duty" (6: 382). Through habituation, one can acquire a maxim of actions in conformity with duty 
without any change at all in one's ultimate end (e.g., the maxim of honest dealing from prudence). Thus Kant remarks in the Religion that virtue in the legal sense (virtus phaenomenon) can be acquired gradually and through "long habituation" without the "slightest change of heart" (6:47)-which would instead require a "revolution in the disposition of the human being (a transition to the maxim of holiness of disposition)" (6:48).

Moreover, Kant thinks that acting on a habit of this sort amounts to a forfeiture of the prerogative to act on the basis of one's own moral judgment and signals instead a willingness to be led by prevalent customs and the expectations of others. The lesson Kant draws from the account of a habitual virtus phaenomenon is thus that moral education requires a cultivation of the pupil's own moral judgment (6:48). And in the Lectures on Pedagogy, Kant expands on this point, telling us that this kind of discipline merely creates a habit of good behavior in the pupil such that "he will become a human being who cares only how he can get on well in the world and is good or bad depending on what he finds most conducive to that end" (9:480f.). But what is important for our purposes is how Kant characterizes the alternative: "one must see to it that the pupil acts from his own maxims, not that he does the good, but that he does it because it is good" (9:475). Only if the pupil learns to act from his own maxims can he avoid learning, e.g., to be truthful because that is what other people expect of him. In the latter case, there is a sense in which truthfulness would not be his own end, not something he does on principle; truthfulness would rather be merely an effect of his willing that serves (more or less adequately) his own further prudential ends. (These ulterior ends are often hidden-even from the agent himself.) Such a person would be, at best, like the mere "imitator (in moral matters)" who lacks a character of his own and thus lacks "originality in the way of thinking" (Anthropology 7:2933-5). For an agent to have a character indicative 
of authentic virtue, by contrast, "he must have his own will [ein eigener Wille], i.e., he must not let himself be led by others" (Anthropologie Reichel 25:1356); that is, he must think for himself rather than conforming to the expectations of others. ${ }^{31}$ Virtue requires enlightenment over our self-incurred "minority" (What is Enlightenment? 8:35). $3^{2}$ In this way, Kant's account of moral education aims to fulfill the ideal he finds in Rousseau's Émile: "that education be free and also make a free human being" (Remarks on the "Observations" 20:1673-4). Only actions chosen in this spirit of freedom could be morally as opposed to merely legally good.

All of this gives us a way to understand Kant's puzzling claim that "if the practice of virtue were to become a habit, the subject would suffer loss to that freedom in adopting maxims which distinguishes an action done from duty" (6:409). Read alone, this claim seems to imply that only the adoption of a moral maxim exemplifies the control over our own willing or choosing that is required for moral responsibility, i.e., transcendental-practical freedom. But the context in which this claims appears allows us to see that Kant is warning against the attitude of mind at the basis of a mere virtus phaenomenon: the agent does not choose his maxim with an attitude of moral freedom marked by an interest in the action itself; the agent instead chooses the maxim either from simple conformism or because he hopes such a conformity will serve some further purpose. In either

\footnotetext{
${ }^{31}$ Kant makes the same point in the earlier Anthropologie Mrongovious (25:1386) and in

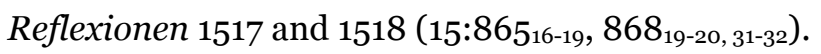

${ }_{32}$ "It is because of laziness and cowardice that so great a part of humankind, after nature has long since emancipated them from other people's direction (naturaliter maiorennes), nevertheless gladly remains minors for life, and that it becomes so easy for other to set themselves up as their guardians." In the Enlightenment essay, Kant's particular concern is that superstition and the ecclesiastical mediation within an authority-based (rather than rational) religious belief condemn people to have, at best, a virtus phaenomenon.
} 
case, he places his aspirations in something beyond his control, making himself dependent on things and especially other people. And this reading seems to be confirmed in Kant's remark on inner freedom: after describing the moral aptitude as "free," he immediately proceeds to identify inner freedom with having a noble (erecta) rather than a base or slavish character (indoles abiecta, serva) (6:407). In these terms, the person who aims at merely lawful behavior chooses his maxim in a servile spirit (with an indoles servilis)-always seeking to gain rewards or to evade punishments-rather than in a noble spirit of a free man (indoles erecta, ingenua).33 The person of character is concerned with his action itself (that is, with the maxim of his action) and not with rewards and punishments; hence he acts as a free person who cannot be hindered or coerced by others. Thus: "The less a human being can be coerced by natural means and the more he can be coerced morally (through the representation of duty), so much more free he is" $\left(6: 382 n ; c f .381_{4-9}\right) .34$ Kant invites a further comparison here between the inner

33 Kant remarks: "Indoles servilis est vel mercenaria, seeking reward, or else actually slavish [knechtish], from fear of punishment” (Metaphysik Dohna [1792-1793], 28:678f.). Thus: "The way of thinking which is won over only by reward is called indoles servilis; that which acts only for the sake of duty is indoles erecta" (Moral Mrongovious 29:624; cf. Moralphilosophie Collins 27:287; Metaphysik der Sitten Vigilantius 27:549f.). This distinction derives, unsurprisingly, from Baumgarten. In Baumgarten's version of the distinction, if the higher, intellectual faculty is dominant, then the subject has a noble character (indoles erecta); but if the lower, sensible faculty of desire is dominant-with the higher merely serving the lower-then the subject has a base character (indoles abjecta). The base character is still free since the lower faculty does not overpower the higher faculty, but rather entices it. See Metaphysica §§730-732 (17:138f.) and Ethica philosophica §248 (27:801).

34 This is clearly a version of the Stoic claim that no one can coerce the sage since he does not consider even his body as something "his own." Thus Kant even says of the Stoic sage: "he cannot be coerced insofar as he coerces himself" (Moralphilosophie Kaehler, p. 18; Moralphilosophie Collins, 27:250 $\mathrm{O}_{2-7}$ ). It therefore seems unlikely that Kant means to refer here to degrees of transcendental-practical freedom (which would be of doubtful coherence anyway). 
freedom of virtue and the moral freedom of the Socratic sage by linking the servile character with passions and affects and the noble character with healthy condition of the person who has overcome these, thereby achieving a "tranquil mind" (6:407-9) (the atarxia of the ancients). And it is in Kant's account of the passions that a more definite account of moral slavery emerges, one that encompasses not just a lack of virtue, but positive evil.

\section{Affects, Passions, and Reason}

For the Stoics, the contrast to the sage who is free because he aims at nothing other than his own virtuous disposition is the ordinary foolish person whose passions (pathê/perturbationes) subject him to forces outside of his control. These passions not only make the ordinary person unhappy and psychically unhealthy, they also make him unjust. In light of Kant's endorsement of the ideal of the sage, it is not surprising that he also endorses the Stoic principle of apathy, "namely that the sage must never be in a state of affect [im Affect], not even of sympathy [Mitleid] for his best friend's misfortune" (Anthropology 7:25321-24; $c f$. GMS 4:398 12-20 .35 But for Kant, this Stoic principle is inadequate insofar as it underestimates what must be overcome to attain this practical ideal: the Stoics

35 For Kant, apathy does not imply that the sage lacks feelings for his friends altogether. Lara Denis points to a comment in Kant's lectures on ethics: "As to the direction of the mind in regard to the affects and passions, we distinguish them [...] from the feelings and inclinations. One may feel something and be inclined to it without having affect or passion over it" (Moralphilosophie Collins, 27:368; also see Menschenkunde 25:11227-16). Denis remarks: "This suggests that apathy is characterized not by a lack of feeling about actual or possible states of affairs, but rather by a commitment to morality such that one's feelings do not become affects, which preempt or interfere with rational reflections" (Denis 2000: 53). She points out that Kant therefore can distinguish "coldness," which is "a want of affect in love," from "frigidity," which is "a want of love" (53; cf. Moralphilosophie Collins, 27:420). She concludes that sage feels for his friend, but that "he does not let those feelings of love or sadness interfere with his agency" (54). 
"send forth wisdom against folly, which lets itself be deceived by inclinations merely because of carelessness, instead of summoning it against the malice (of the human heart)" (Religion 6:57). Mere "folly" would presumably bring a mere lack of virtue-akin to what Kant calls the mere "weakness" or "frailty" of human nature in following its good maxims-rather than evil proper, which indicates a positive corruption or depravity (6:29-30, $M d S$ 6:407-8). ${ }^{36}$

Although Kant highlights the insufficiency of the principle of lack of affect, he nevertheless marks out the whole topic of ethical duties in a way reminiscent of the Stoic ideal of lack of passions: the inner freedom of virtue presupposes not just lack of affect, but also "dominion over oneself" (Herrschaft über sich selbst, über sich selbst Herr sein) which Kant equates with "dominating one's passions" (Leidenschaften beherrschen) (MdS 6:407-8). And although we can infer from his criticism of the Stoics that Kant thinks that passions, when properly understood, indicate a kind of perversity or corruption that the Stoics (as heathens) failed to notice, Kant's own account of the passions remains faithful to the Stoic doctrine in the following important ways: a passion (1) is not a merely natural error, but rather arises from our reason and hence (2) is something for which we are responsible and that (3) is associated with vice and (4) moral slavery.

Kant describes passions and affects in terms of a kind of corruption of the deliberative process. An affect is "the feeling of pleasure or displeasure in the subject's present state that does not let him rise to reflection (the representation by means of reason as to whether he should give himself up to it or refuse it" (Anthropology 7:251); it "makes itself incapable of pursuing its own end" and

${ }^{36}$ In this regard, it is significant that Kant complains that Baumgarten failed to see that the affects and passions differ in kind rather than merely degree (Menschenkunde 25:1115) 
even "makes us (more or less) blind" (7:253). A passion, for its part, is the "folly" of "making part of one's end the whole" (7:266). Moreover, a passion is an inclination "that excludes mastery over itself" (Religion 6:28n) and "that can be conquered only with difficulty or not at all by the subject's reason" (7:251); indeed, passions are "for the most part incurable because the sick person does not want to be cured and flees from the dominion of principles, by which alone a cure could occur" (7:266; $c f . K d U 5: 272 n)$. All of this might seem to suggest the affects and passions bring a forfeiture of the control over choices characteristic of transcendental-practical freedom.

We might say in this regard that the person in the grips of an affect or passion is like the drunken person: although he cannot deliberate properly while drunk, he did choose to drink knowing the potential for bad behavior that could result, and he is thus responsible for what he does while drunk (Metaphysik der Sitten Vigilantius 27:559). On such an account, we can say that even the drunk person retains his transcendental-practical freedom: he remains the free cause of all that results from his drunkenness even while he is drunk; he is the "author" and "efficient first cause" of the action; "i.e., the determining ground of the action can be sought nowhere else in nature" (27:558-9).37 This is not surprising once we recall that, for Kant, the kind of control characteristic of transcendental-practical freedom is not any case an ability to disrupt the temporal order of events,

37 Kant is presumably familiar with Aristotle's version of this claim: "we punish a man for his very ignorance, if he is thought responsible for the ignorance, as when penalties are doubled in the case of drunkenness, for the moving principle is in the man himself, since he had the power of not getting drunk and his getting drunk was the cause of his ignorance" (Nicomachean Ethics 1113b30-34). Hence Aristotle adds: "And we punish those who are ignorant of anything in the law that they ought to know [...] we assume that it is in their power not to be ignorant, since they have the power of taking care. Still they are themselves by their slack lives responsible (aitioi) for becoming men of that kind, and men make themselves responsible for being unjust or selfindulgent" (1113b34-1114a7). This passage is discussed by Walter Ott (2006). 
including the psychological order of deliberation. In particular, transcendentalpractical freedom is not the control of our deliberation from one point in time to the next. To that extent, Kant is in agreement with the compatibilists-including, significantly, Stoic compatibilists. For this reason, it would be a mistake to think that the deliberative disruption engendered by the passions and affects could be a closing off of future free choices: that future choices are closed off by the past is a general feature of the temporal order, not something pathological. ${ }^{8}$ Hence when Kant says that it is in our power right now to do as duty requires despite all sensible inclinations to the contrary (e.g., $M d S$ 6:380 $0_{7-12}$ ), he does not mean that the present is indeterminate with respect to the future. He means rather that our practical character is itself something for which we are responsible since it is something freely chosen; it is our intelligible character, which, in turn, is the ground of the temporal order of our actions (KrVA541-546/B569-574; Reflexion 5612 18:25321-31). And part of that character is the influence we allow the affects to have. But the basic point can be made without appeal to Kant's account of timeless agency: the affects prevent reflection on the part of the agent only because the agent's own character allows them to have this effect. Hence Kant says regarding natural inclinations as obstacles to virtue: "it is the human being himself who puts these obstacles in the way of his maxims" (MdS 6:394; cf. GMS $4: 457-8)$.

38 "Now, since time past is no longer within my control, every action that I perform must be necessary by determining grounds that are not within my control, that is, I am never free at the point of time in which I act" ( $K p V$ 5:9433-36). See Wood 1984: esp. 89-93. Kant is certainly sensitive to the compatibilists' worry that the possibility of such a disruption of the temporal order of deliberation would free the subject from determinism only at the price of making his actions seem as if they were a matter of chance and hence not sometime imputable. In the Nova dilucidatio of 1755 , Kant criticizes a Crusian incompatibilism on similar grounds (1:402). 
However, this model of responsibility is more appropriate for our failure to subdue our affects than for governing our passions. Kant remarks about the passions: "It is also easy to see that they do the greatest damage to freedom, and if affect is drunkenness, then passion is an illness that abhors all medicine" (7:265-6). At times, Kant seems to suggest that the most important difference between passions and affects in this regard is that passions are more permanent: an affect is a feeling that can quickly subside, whereas a passion is "a sensible desire that has become lasting inclination." And it seems to be this permanence that is morally problematic: a passion is calm and hence "allows the mind to form principles upon it and so [...] to incorporate what is evil (as something intentional) into one's maxim. And then the evil is properly evil, that is, a true vice" (MdS 6:408).

This longevity or incurability of the passions signals a state of mind that is relatively immune to revision in light of favorable or unfavorable results. In that regard, the passions mimic the firm principles of character. And this is closely connected to a more fundamental feature of passions that distinguishes them from affects: the passions are rooted in practical principles that make the evil "intentional." 39 Affects are either a substitute for a properly resolute maxim of virtue or else they disrupt the implementation of otherwise good maxims. (In the latter case, this disruption is still something for which we are responsible, something that can be traced to a higher maxim.) A passion, on the other hand, is not something that we merely allow to interfere with the operation of reason: far from being a weakness with respect to the inclinations, a passion makes one "blind" to other sensible incentives whose satisfaction would be needed for

\footnotetext{
39 Recall that Kant says that guilt arising from frailty and impurity is unintentional (unvorsätzlich, culpa), whereas the guilt arising from depravity or corruption is intentional (vorsätzlich, dolus).
} 
happiness (7:267). A passion instead results from a corruption of reason itself. Kant explains, for example, that physical love is not a passion since

it does not contain a constant principle with respect to its object. Passion always presupposes a maxim of the subject to act in accordance with an end prescribed to him by inclination. So it is always connected with his reason, and we can no more attribute passion to mere animals than to pure rational beings.

[7:266; emphasis altered]

"Accordingly, the outbreak of a passion can be imputed [zugerechnet] to the human being" (7:269). Some passions have a more direct connection with maxims than others. Thus, although Kant says that all passions presuppose a maxim, he also tells us that the acquired passions of culture, unlike the innate passions of nature, "are not connected with the impetuosity of an affect but with the persistence of a maxim established for certain ends" (7:268).

The kind of deliberative disruption that Kant seems to have in mind here ("making part of one's end the whole") recalls the Stoics' own account of the cognitive error embodied in the passions. For the Stoics, it is an unhealthy passion to consider something like money to be good (rather than merely a "preferred indifferent"). To consider such an end good would be to consider it choiceworthy in all circumstances, and such a passion therefore stands opposed to virtue, which alone is choiceworthy in all circumstances. In terms closer to Kant's, we can say that although having an end of attaining money contributes to the end of happiness and can even be consistent with the end of morality, to make the possession of money the whole of one's end is to exclude the end of morality (not to mention happiness). Hence Kant remarks that "making part of 
one's end the whole" is something that "directly contradicts the formal principle of reason itself" (7:266). According to the Stoics, we are responsible for what we do as a result of our passions since our passions are an expression of our own practical character. $4^{\circ}$ And Kant, by associating passions with maxims, can be seen to be presenting an analogous view. Regarding this "folly," Kant remarks:

That is why passions are not, like affects, merely unfortunate states of mind full of many ills, but are without exception evil as well. And the most good-natured desire, even when it aims at what (according to matter) belongs to virtue, for example, to beneficence, is still (according to form) not merely pragmatically ruinous but also morally reprehensible, as soon as it breaks out into a passion. Affect does a momentary damage to freedom and dominion over oneself. Passion abandons them and finds its pleasure and satisfaction in a slavish mind.

$[7: 267]$

\section{The Moral Slavery of the Passions}

The connection of passions with maxims explains why we are responsible for our passions, but it does not yet explain why passion should be associated with finding "pleasure and satisfaction in a slavish mind.” Affects are also incompatible with wisdom and the self-mastery required for inner freedom. The agent under affect lacks "wisdom" and is instead a "fool" (Menschenkunde $25: 1121)$. Such an agent cannot be said to be in control of his fate since he is not even able to pursue the end that he himself thinks would give him satisfaction.

$4^{40}$ For an account of the Stoics' own version of such a view, see Strange 2004. 
And Kant suggests in lectures that this loss of control allows other people to assume control:

the other thereby gains the upper hand over us. [...] If one is under an affect, one completely relinquishes power to the other. [...] A mean person wants to frighten the other, but the other surely sees that he can play the master over him as long as he remains in this condition.

[Menschenkunde 25:1119]

With a passion, by contrast, this relinquishing of power to the other is something intentional. The passionate person does not place his aspirations in an end that his reason can attain all by itself; instead, he places his highest aspirations under the control of other people and thereby becomes their slave. And it is in this pathological relation to others that true evil can be found.

Kant makes the surprising claim in this connection that passions are not desires for any particular things; they are rather desires "concerned merely with the possession of means" (7:2708-10). Moreover: "Properly speaking, passions are always directed only by human beings to human beings, not to things," such that the passions "can be satisfied only by them" (7:2686-7, $\left.270_{3-5}\right)$. Kant explains in lectures: "The cause of this is that the human being is the principle means to the satisfaction of all inclinations"; "our inclinations are directed to nature, but by means of human beings" (Menschenkunde 25:1141f.). Kant mentions the inclinations of (outer) freedom and sex along with the desire for vengeance as "passions of natural (innate) inclination." ${ }^{41}$ Kant does not treat this class of

\footnotetext{
${ }^{41}$ Kant remarks in lectures: "The human being that is hindered from living according to his inclination is not free; this hindrance from living according to his inclination is introduced by human beings. [...] These hindrances from living according to our inclination are always
} 
passions in a systematic way, but more relevant to the origin of evil are the passions based on "acquired" inclinations, that is, inclinations that "proceed from human culture [Cultur].” The passions arising from this inclination are ambition, lust for power, and greed (Ehrsucht, Herrschsucht, and Habsucht):42

[B]ringing other people's inclinations into our power, so that we can direct and determine them according to our own purposes, is almost the same thing as possessing other men as mere tools of our will. [...] This ability [to influence others] contains, as it were, a threefold force: honor, power, and money [Ehr, Gewalt, und Geld]. If we have these we can get at every person-if not through the influence of one, then through the others-and use him for our purposes.

[Anthropology 7:27118-27]

The passions based on the desire for honor, power, and money concern "the inclination to the ability to have a general influence over other people," an inclination that "comes closest to technically practical reason, that is, to the maxim of prudence [Klugheitsmaxime]" (7:271; cf. Anthropologie Petersburg 25:1141f.). These passions are thus closely connected with prudence, and in

introduced to us by human beings; thus our inclination to freedom is directed solely at human beings. [...] The human being feels unhappy under the most benevolent master if his happiness depends on the inclination of this master. From this it follows that freedom is the condition under which the human being can be happy" (Anthropologie Petersburg 25:1142f.).

42 Louden suggests the more literal translation of "mania for honor," "mania for domination," and "mania for possession." This list of passions can be compared to Kant's claim in the opening of the first section of the Groundwork that "power, wealth, and honor" (Macht, Reichthum, Ehre) are not "good without limitation": they can be good only if "a good will is present by which their influence on the mind-and thereby the whole principle of action-can be corrected and made to conform with universal ends" (4:39314-19). 
particular with what Kant calls "worldly prudence" (Weltklugheit): "skill in influencing others so as to use them for our purposes" ( $G M S$ 4:416n). Yet when this inclination is elevated into a passion, our happiness is actually thwarted. The problem is rooted in the fact that the passions of acquired inclinations thus "consist in valuing the mere opinions of others regarding the worth of things as equal to their real worth" (7:270). To take an important example, it is natural and prudent that we should want to be held in esteem by others. But when we become ambitious, we take our whole happiness to consist in our social status; we take our whole worth to consist in the opinions others have of us. And insofar as we place our aspiration for happiness in a comparison with others, we simply give ourselves new reason to be unhappy.

Despite this, it might seem surprising that the passions would make one servile. After all, the root of the passions is our desire for just the opposite: to be free from the domination of others and to dominate them instead. But precisely because the passions are aimed, in this way, exclusively toward other people, the passionate person depends entirely and directly on other people for the satisfaction he seeks. Consequently, whereas the passions may seem to bring a kind of strength to their possessors, they are each in actuality a "weakness" by means of which the passionate person can be exploited by others:

Ambition, lust for power, and greed are weaknesses people have on account of which one can have influence over them through their opinion, their fear, and their own interest, respectively. Each of these is a servile disposition by means of which another person, when he has made himself master of it, has the ability to use a man through his own inclinations.

[Anthropology, 7:2726-11] 
For example, Kant says of ambition: "One need only flatter this pride, and by means of the fool's passion one has him in one's power" (7:272 $18-22)$. Although the desire for honor is rooted in the desire to control other people, when this desire becomes the passion of ambition, the ambitious person actually becomes subservient to others since his satisfaction depends entirely on their approval. And in that case, the ambitious person is just as subservient to the flatterer as the flatterer is to him. And this pathological social relation is not restricted to my relation to other human beings. If I view the authority of moral demands as resting on divine threats or promises, then I implicitly treat God as a person who is possessed by passions: I would represent God as possessed by "desire for honor and power [Ehr- und Herrschbegierde] combined with dreadful representations of power and vengefulness" (GMS 4:44310-19).

The connection of these passions with a positively vicious disposition is fairly straightforward. In the Religion, Kant makes this connection explicit: it is the passions-envy, lust for power, and greed, in particular-that corrupt the human being's originally good predisposition (6:93).43 If I am possessed by one of these passions, then I seek status, power, and money not simply for their own sakes, but rather as a force by means of which I can control other people: I value these things ultimately only because other people value them and because I believe possessing them will therefore allow me to direct their free choice to ends that serve my own. Therefore, if I am possessed by a passion, I implicitly deny the dignity of the free, rational beings I seek to control, treating them not as ends in

43 Allen Wood (1999: 286-290) emphasizes the social and historical context of human evil and relates this to his detailed overview of Kant's account of the passions (253-265). My focus, however, is on the slavery of the passions. 
themselves (as "persons"), but rather using their free choice as a mere means for promoting my own happiness (as "things").

The idea that the passionate person-the person who values wealth, honor, etc., as good without qualification-is a slave because he subjects himself to other people by means of his passions is already part of classical Stoic doctrine. 44 But the Stoics see the slavery to others engendered by the passions as merely an extension of our dependence on things. 45 In taking the passions to be essentially social dependencies, Kant shows his debt to Rousseau. ${ }^{46}$ Like Kant after him, Rousseau sees the slavishness of the passions, especially ambition, as intimately connected with evil and the corruption of society. What Kant takes from Rousseau is the view that the real source of unhappiness and vice is not our natural needs (which we have already in the state of nature), but rather the pathological social dependence engendered by the passions.

Rousseau opens the first chapter of the first book of his Social Contract with the famous sentence: "Man is born free, and he is everywhere in chains." Less famous is the next sentence: "One believes himself the others' master, and yet is

44 For example, Epictetus remarks: "Whenever, therefore, you see a man groveling to another, or flattering him contrary to his own opinion, confidently say that he too is not free; and not only if he is doing so for the sake of a wretched dinner, but even if it be for a governorship or indeed a consulship; you should call those who are acting in this way for the sake of little things, petty slaves, and the rest, as they deserve, slaves in the grand manner (Epictetus, Discourses 4.1.55).

45 “Each person's master is the one who has power over what that person wants or does not want, so as to secure it or take it away. Whoever, then, wants to be free, let him neither want anything, nor avoid anything, that depends on others; otherwise he must necessarily be a slave" (Epictetus, Handbook 14).

${ }^{46}$ In some cases, Kant apparently follows the details of Rousseau's account quite closely. Examples are his remark that a child's cry is a "claim to freedom" (7:268; $\left.c f .20: 88_{5-9}\right)$, his account of the manner in which women gain dominance over men (7:273), and his description of a passion as an illusion that consists in mistaking others' opinions for the real worth of something. 
more a slave than they." 47 While Rousseau is certainly concerned with the problem of what Kant calls "outer," political freedom, he is just as often concerned with the inner freedom attained by extirpating the slavish passions (especially ambition) and pursuing virtue. And like Kant, he sees the slavishness of the passions as intimately connected with evil and the corruption of society. The following passage is characteristic of Rousseau's view, and its anticipation of Kant's account is unmistakable:

[M]an, who had previously been free and independent [viz, before the division of labor and the institution of property] is now so to speak subjugated by a multitude of new needs to the whole of nature, and especially to those of his kind, whose slave he in a sense becomes even by becoming their master; rich, he needs their services; poor, he needs their help, and moderate means do not enable him to do without them. He must therefore constantly try to interest them in his fate and make them really or apparently find their own profit in working for his: which makes him knavish [fourbe] and artful with some, imperious and harsh with the rest, and places him under the necessity of deceiving all those he needs if he cannot get them to fear him and does not find it in his interest to make himself useful to them. Finally,

47 On the Social Contract I i $\llbracket 1$. Rousseau shows his debt to the Socratic tradition when he says that the man who has the true courage and strength to overcome his passions "rules no less in chains than on the throne" ("Discourse on the Virtue a Hero Most Needs or On Heroic Virtue" I36f.). Kant, for his part, shows a keen awareness of the political metaphor contained in the conception of the freedom of the sage: "someone who has the power to leave this world when he chooses cannot be subjugated to anyone, does not let himself be prevented by anything from telling the harshest truths to the greatest tyrants; for he cannot be coerced to do so by any torment since he can quickly leave this world just as a free man can leave the city when he chooses" (Moralphilosophie Kaehler, p. 279). 
consuming ambition [l'ambition], the ardent desire to raise one's relative fortune less out of a genuine need than in order to place oneself above others instills in all men a black inclination to harm one another, a secret jealousy that is all the more dangerous as it often assumes the mask of benevolence in order to strike its blow in greater safety: in a word, competition and rivalry on the one hand, conflict of interests on the other, and always the hidden desire to profit at another's expense; all these evils are the first effect of property, and the inseparable train of nascent inequality. [Second Discourse, II 27]

Only Rousseau's emphasis on the role of property in the origin of these pathological social relations distinguishes this account of moral slavery from Kant's. Moreover, Rousseau, like Kant, connects the kind of inner slavery he describes in this passage with the passions and suggests that extirpation of the passions in the manner of a Stoic sage is a means of becoming a virtuous and a free man. It is true that Rousseau emphasizes, more than Kant, the ability of external laws to moderate these passions (by forcing citizens to act for the common good rather than for their own selfish good) and thereby to foster such a "moral freedom" in the citizens subject to the law. ${ }^{48}$ But Kant's account of history

48 "To the preceding one might add to the credit of the civil state [not only civil but also] moral freedom, which alone makes man truly the master of himself; for the impulsion of mere appetite is slavery, and obedience to the law one has prescribed to oneself is freedom" (On the Social Contract I viii ๆ3). Hence a well ordered society will be characterized by "stoicism” (IV viii 927). Kant also sees a role for political legislation in ensuring our moral progress, but the community of individuals that ultimately allows for the flourishing of virtue is not a political community, but rather a merely ethical community. Nevertheless, Rousseau does not equate moral and political freedom nor does he think moral freedom necessarily presupposes political freedom: "Freedom is found in no form of government; it is in the heart of the free man. He takes it with him everywhere. The vile man takes his servitude everywhere. The latter would be a slave 
also holds out hopes that moral improvement could be encouraged by a just political order.

Rousseau is happy to speak about the "perfectibility" of the human being without entering into the metaphysical debates about the nature of free will: Rousseau is a psychologist and moral theorist, not a metaphysician. He therefore leaves aside metaphysical questions about "free will" when speaking about the slavery and freedom of man. This is already clear from the wholly social character of the dependencies engendered by the passions. For Rousseau, it is precisely these social dependencies-and not some property of the will that could be specified in abstraction from these relations-that lead to our unhappiness and moral corruption.

Unlike Rousseau, Kant places the metaphysics of free will at the center of his entire philosophical project (e.g. $K p V 5: 3$ f.). But his Rousseauian account of the social dependencies engendered by the passions highlights the fact that Kant, like Rousseau before him, does not see the slavery engendered by the passions as having anything to do with the metaphysics of free will: the passions do not imply a loss, or even diminishment, of our transcendental-practical freedom. 49 Their slavery is moral and thus neither one of physical captivity, nor metaphysical determination. The evil will does not lose its transcendental-practical freedom,

in Geneva, the former a free man in Paris" (Emile, Book V, p. 473). Laws "contain men without changing them" (Second Discourse II 50). Nevertheless: "It is not true that he draws no profit from the laws. They give him courage to be just even among wicked men. It is not true that they have not made him free. They have taught him to reign over himself" (Emile IV, p. 473).

49 His own early account of moral freedom in the Remarks on the "Observations" follows Rousseau not only in seeing moral freedom as distinct from metaphysics, but also in denying the need for a resolution to traditional metaphysical problems. Kant even advocates a "zetetic" (rather than dogmatic) doubt of "postponement": "The method of doubt is useful because it preserves the mind, not for speculation, but for understanding and sentiment” (20:17513-20; cf. Dreams of a Spirit-Seer 2:369f.). 
but rather misuses it by slavishly offering itself to other wills to be used as mere tool. The virtuous will, by contrast, attains its own kind of freedom-not because it alone is fully free from necessity, but rather because it rejects a mercenary or slavish attitude toward its duties and instead fulfills its duties in a spirit of freedom that considers virtue to be its own reward. Only such a will has the selfsufficiency to attain satisfaction through its own activity alone. 


\section{REFERENCES}

Annas, Julia (1995) The Morality of Happiness. Oxford: Oxford University Press.

Aquinas (1905) [Summa Contra Gentiles =] Of God and His Creatures. An Annotated

Translation (with some Abridgement) of the Summa Contra Gentiles of Saint Thos. Aquinas by Joseph Rickaby, S.J. London: Burns and Oates.

Aquinas (1970) Summa Theologiae. Edited T. Gilby. Cambridge: Blackfriars.

Aristotle (1941) The Basic Works of Aristotle. Edited by Richard McKeon. New York: Random House.

Baumgarten, A. G. (1757). Metaphysica, $4^{\text {th }}$ edition. Halle. Reprinted in the "Academy" edition of Kant's works, 17:5-130, 15:5-54, 17:130-226.

Baumgarten, A. G. (1751). Ethica philosophica, $2^{\text {nd }}$ edition . Reprinted in the "Academy" edition of Kant's works, 27:732-1028.

Bobzien, Suzanne (1998). Determinism and Freedom in Stoic Philosophy. Oxford: Oxford University Press.

Denis, Lara (2000). 'Kant's Cold Sage and the Sublimity of Apathy'. Kantian Review 4, 48-73.

Engstrom, Stephen (1997) 'Practical Wisdom'. Kant-Studien 88, 16-43.

Engstrom, Stephen (2002) 'The Inner Freedom of Virtue'. In M. Timmons (ed.) Kant's Metaphysics of Morals: Interpretative Essays (Oxford: Oxford University Press), 289-315.

Epictetus (1995) The Discourses, The Handbook, The Fragments. Edited by Christopher Gill. London: J. M. Dent.

Forman, David (2008) 'Free Will and the Freedom of the Sage in Leibniz and the Stoics'. The History of Philosophy Quarterly 25/3, 203-219.

Forman, David (forthcoming) 'Principled and Unprincipled Maxims'. Kant-Studien.

Frierson, Patrick (2006) 'Character and Evil in Kant's Moral Anthropology'. The Journal of the History of Philosophy 44/4, 623-634.

Frierson, Patrick (2010) 'Kantian Moral Pessimism'. In P. Muchnik and S. Anderson-Gold (eds.), Kant's Anatomy of Evil (Cambridge: Cambridge University Press), 33-56.

Grenberg, Jeanine (2005) Kant and the Ethics of Humility. Cambridge: Cambridge University Press. 
Guyer, Paul (2005) 'Kant on the Theory and Practice of Autonomy'. In Kant's System of Nature and Freedom (Cambridge: Cambridge University Press), 115-145.

Guyer, Paul (2007) 'Naturalistic and Transcendental Moments in Kant’s Moral Philosophy'. Inquiry 50/5, 444-464.

Hudson, Hud (1994) Kant's Compatibilism. Ithaca: University of Cornell Press.

Inwood, B. \& Gerson, eds. (1997) Hellenistic Philosophy. Indianapolis: Hackett.

Kant, Immanuel (1902- ), Kants gesammelten Schriften. Edited by the Königlich Deutschen Akademie der Wissenschaften. Berlin: de Gruyter.

Kant, Immanuel (1991) Bemerkungen in den Beobachtungen über das Gefühl des Schönen und Erhabenen. Edited by M. Rischmüller. Hamburg: Felix Meiner Verlag. (Cited according to the numbering in this edition and the Academy pagination.)

Kant, Immanuel (1992) Theoretical Philosophy, 1755-1770. Translated and edited by David Walford. Cambridge: Cambridge University Press.

Kant, Immanuel (1996a) Practical Philosophy. Edited by Mary Gregor. Cambridge: Cambridge University Press

Kant, Immanuel (1996b) Writings on Religion and Rational Theology. Edited by A. Wood \& G. di Giovanni. Cambridge: Cambridge University Press

Kant, Immanuel (1997) Lectures on Ethics. Edited by P. Heath \& J. Schneewind. Cambridge: Cambridge University Press.

Kant, Immanuel (1998) Critique of Pure Reason. Translated by P. Guyer and A. Wood. Cambridge: Cambridge University Press

Kant, Immanuel (2000) Critique of Judgment. Translated by P. Guyer \& E. Mathews. Cambridge: Cambridge University Press.

Kant, Immanuel (2002) Theoretical Philosophy after 1781. Edited by H. Allison \& P. Heath. Cambridge: Cambridge University Press.

Kant, Immanuel (2005) Notes and Fragments. Edited by P. Guyer. Cambridge: Cambridge University Press.

Kant, Immanuel (2007) Anthropology, History, and Education. Edited by G. Zöller and R. Louden. Cambridge: Cambridge University Press.

Korsgaard, Christine (1996). 'Morality as Freedom', In Creating the Kingdom of Ends (Cambridge: Cambridge University Press), 159-187. 
Leibniz, G. W. (1951) Theodicy: Essays on the Goodness of God, the Freedom of Man, and the Origin of Evil. London: Routledge \& Kegan Paul Limited.

Ott, Walter (2006) 'Aristotle and Plato on Character'. Ancient Philosophy 26, 65-79.

Reinhold, C. L. (1975) 'Erörterung des Begriffs von der Freiheit des Willens'. In R. Bittner \& K. Cramer (eds.) Materialien zu Kants 'Kritik der praktischen Vernunft' (Berlin: Suhrkamp), 252-74.

Rousseau, J.-J. (1997) The Discourses and Other Political Writings. Edited and translated by V. Gourevitch. Cambridge: Cambridge University Press.

Rousseau, J.-J. (1997) The Social Contract and Other Later Political Writings. Edited and translated by V. Gourevitch. Cambridge: Cambridge University Press.

Rousseau, J.-J. (1979) Emile: Or On Education. Translated by A. Bloom. New York: Basic Books.

Schneewind, Jerome (1998) 'Kant and Stoic Ethics'. In S. Engstrom and J. Whiting (eds.), Aristotle, Kant, and the Stoics: Rethinking Happiness and Duty (Cambridge: Cambridge University Press), 205-301.

Shaftesbury [Anthony Ashley Cooper] (1999), Characteristics of Men, Manners, Opinions, and Times. Cambridge: Cambridge University Press.

Shell, Susan Meld (2007) 'Kant and the Jewish Question'. Hebraic Political Studies 2/1, 101-136.

Sidgwick, Henry (1888) ‘The Kantian Conception of Free Will'. Mind (old series) 13, 405-412.

Strange, Steven (2004) 'The Stoics on the Voluntariness of the Passions'. In Steven K. Strange and Jack Zupko (eds.), Stoicism: Traditions and Transformations (Cambridge: Cambridge University Press), 32-51.

Velkley, Richard (1989) Freedom and the End Reason. Chicago: University of Chicago Press

Wolff, Christian (1733). [German Ethics =] Vernünfftige Gedancken von der Menschen Thun und Lassen zu Beföderung ihrer Glückseeligkeit, den Leibhabern der Wahrheit mitgetheilt. Frankfurt and Leipzig. [11720].

Wolff, Christian (1751). [German Metaphysics =] Vernünfftige Gedancken von Gott, der Welt und der Seele des Menschen, auch allen Dingen überhaupt, den Liebhabern der Wahrheit mitgetheilt. Halle. [11720].

Wood, Allen (1984) 'Kant's Compatibilism'. In A. Wood (ed.), Self and Nature in Kant's Philosophy (Ithica: Cornell University Press), 73-101. 
Wood, Allen (2005). “Kant's History of Ethics," Studies in the History of Ethics, June Wood, Allen (1999) Kant's Ethical Thought. Cambridge: Cambridge University Press.

Zammito, John (2002) Kant, Herder, and the Birth of Anthropology. Chicago: University of Chicago Press. 